\title{
Intraventricular tumor presenting as progressive supranuclear palsy-like phenotype
}

Figure 3 Tesla brain MRI findings
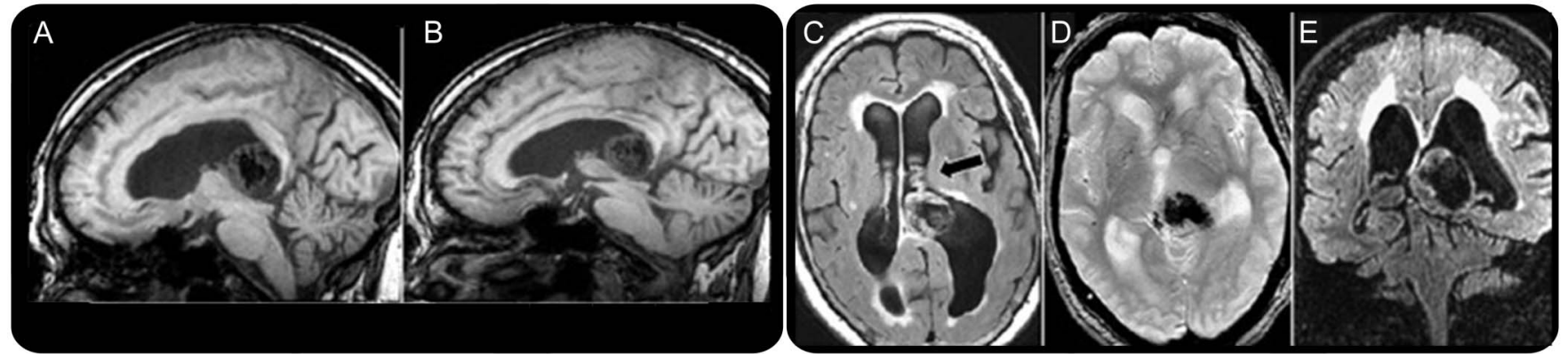

Sagittal T1-weighted images (A, B): midbrain compression caused by a globular tumor. Axial fluid-attenuated inversion recovery (FLAIR) image (C): left lateral ventricle enlargement; vascular pedicle connecting the tumor to the choroidal plexus (arrow). Axial-GE-T2* image (D): tumor hypointensity by mineral accumulation. Coronal FLAIR image (E): left cerebral peduncle dislocation and transependymal CSF diffusion.

A 70-year-old woman presented with a 2-year history of progressive difficulty in walking with frequent falls. Neurologic examination showed postural instability with backward falls, vertical supranuclear gaze palsy with normal vestibular-ocular reflex, rigidity, and pyramidal signs in the right limbs. There was no clinical response to levodopa. Laboratory serologic tests had normal results. MRI displayed midbrain compression and dislocation caused by a large tumor in the left lateral ventricle (figure). Dopamine transporter SPECT showed normal striatal binding. The patient died before neurosurgery could be performed; there was no autopsy. Brain tumors should be considered in the diagnostic workup ${ }^{1}$ of progressive supranuclear palsy-like phenotypes.

Maurizio Morelli, MD, Francesco Fera, MD, Francesco Bono, MD, Alessandra Fratto, MD,

Gennarina Arabia, MD, MSc, Aldo Quattrone, MD

From the Institute of Neurology (M.M., F.B., A.F., G.A., A.Q.), University Magna Graecia, Catanzaro, Italy; and the Neuroimaging Research Unit (F.F., A.Q.), National Research Council, Catanzaro, Italy.

Author contributions: Dr. Morelli: drafting the manuscript, acquisition of data, analysis and interpretation of data, accepts responsibility for conduct of research and final approval. Dr. Fera: acquisition of data, analysis and interpretation of data, accepts responsibility for conduct of research and final approval. Francesco Bono: acquisition of data, accepts responsibility for conduct of research and final approval. Dr. Fratto: acquisition of data, accepts responsibility for conduct of research and final approval. Dr. Arabia: acquisition of data, accepts responsibility for conduct of research and final approval. Dr. Quattrone: corresponding author; study concept and design, drafting/revising the manuscript, study supervision, accepts responsibility for conduct of research and final approval.

Study funding: No targeted funding reported.

Disclosure: The authors report no disclosures relevant to the manuscript. Go to Neurology.org for full disclosures.

Correspondence to Dr. Quattrone: quattrone@unicz.it

1. Lewerenz J, Zurowski B, Jenicke L, Bäumer T, Lees AJ, Münchau A. Lesion of the dorsorostral midbrain sparing the nigrostriatal tract mimics axial rigidity seen in progressive supranuclear palsy. Mov Disord 2005;20:1071-1075. 


\section{Neurology}

Intraventricular tumor presenting as progressive supranuclear palsy-like phenotype Maurizio Morelli, Francesco Fera, Francesco Bono, et al.

Neurology 2014;83;948

DOI 10.1212/WNL.0000000000000748

This information is current as of September 1, 2014

$\begin{array}{ll}\begin{array}{l}\text { Updated Information \& } \\ \text { Services }\end{array} & \begin{array}{l}\text { including high resolution figures, can be found at: } \\ \text { http://n.neurology.org/content/83/10/948.full }\end{array} \\ \text { References } & \text { This article cites } 1 \text { articles, } 0 \text { of which you can access for free at: } \\ \text { http://n.neurology.org/content/83/10/948.full\#ref-list-1 } & \text { This article, along with others on similar topics, appears in the } \\ \text { following collection(s): } & \text { MRI } \\ \text { http://n.neurology.org/cgi/collection/mri } \\ \text { Primary brain tumor } \\ \text { http://n.neurology.org/cgi/collection/primary_brain_tumor } \\ \text { Progressive supranuclear palsy } \\ \text { http://n.neurology.org/cgi/collection/progressive_supranuclear_palsy } \\ \text { Information about reproducing this article in parts (figures,tables) or in } \\ \text { its entirety can be found online at: } \\ \text { http://www.neurology.org/about/about_the_journal\#permissions } \\ \text { Permissions \& Licensing } \\ \text { Information about ordering reprints can be found online: } \\ \text { http://n.neurology.org/subscribers/advertise }\end{array}$

Neurology ${ }^{\circledR}$ is the official journal of the American Academy of Neurology. Published continuously since 1951, it is now a weekly with 48 issues per year. Copyright () 2014 American Academy of Neurology. All rights reserved. Print ISSN: 0028-3878. Online ISSN: 1526-632X.

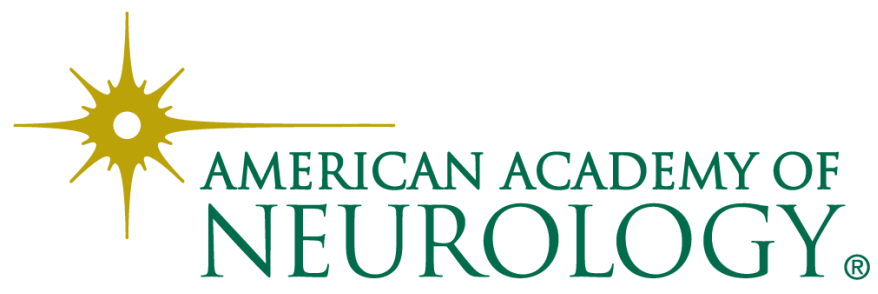

